The Geneva Papers on Risk and Insurance, 23 (No. 87, April 1998), 147-151

\title{
Current Problems in the Law and Economics of Private Insurance: an Introduction
}

\author{
by Herman Cousy*, Paul Fenn** and Roger Vandenbergh***
}

The present volume comprises a selection of papers which were presented at the seventh Joint Conference of the Geneva Association and the European Association of Law and Economics, held in Hamburg on April 7 and 8, 1997. The Call for Papers announced three preferential topics which lie quite apart from each other, but which have in common (and were chosen for the reason) that they relate to three well-known and sensitive problems facing the insurance industry today; 1 . long tail (liability) risks and claims made policies; 2 . competition on insurance markets (and information of the consumer); 3 . the relation between private insurance and complementary social insurance. The actual harvest of papers has added a couple of other themes to the list, namely legal expense insurance and also (one paper on) the classical issue of development risks and liability systems.

\section{Long tail liability risks}

The issue of the long tail (liability) risks is well known to the insurance industry. Due to both technological and legal developments, an ever growing space of time elapses between the moment where the initial damage causing event takes place, and the moment where the loss occurs and the moment where the claim for damages is brought. The problem arises inter alia in cases of environmental impairment liability, of asbestos litigation, of exposure to toxic substances, in some cases of product liability and also in cases of professional liability (one thinks about medical professionals, lawyers, accountants, etc.).

\footnotetext{
* University of Leuven

** University of Nottingham

*** University of Hamburg
} 
The paper of Jaap Spier on "Long tail (liability) risks and claims made policies" first puts forward a number of general observations concerning the attitude which insurers should adopt toward the alarming problems caused by liability claims. Starting from the observation that the use of claims-made policies, which seems to be the obvious solution to the problem, is heavily criticized by legislators, courts and doctrinal writings and wondering why these claims made policies are still relatively rare in Europe, Jaap Spier adamantly argues that claims made policies are not unfair and not unreasonably burdensome for the insured. The only serious disadvantage for the insured is the possibility that he might face a gap in the coverage, a problem which, so the author argues, should be met by the use of instruments like retroactive cover, an extended notification period and the so-called "circumstances clause" (a clause by virtue of which coverage will be extended to post-contract claims, arising out of "circumstances" notified to the insurer before the end of the contract), and mainly by careful information to the consumer. The fact that a claims-made coverage allows the insurer to get rid of risks he is no longer prepared to run, is not considered to be unreasonable or unfair.

Stressing the social function of liability insurance, the paper of Geert Schoorens and Caroline Van Schoubroeck argues that both the switch to loss occurrence/claims made policies and the tendency to confine coverage of claims after the expiry of the contract to a fixed time-period, do give rise to a troublesome inadequacy of coverage.

The authors reformulate and narrow down the scope of the problem to a question of insurability. The longer the time-lapse between fact and claim, the greater the odds that insurers are faced with loss ratios they could not have foreseen initially.

They subsequently show that many of the above-mentioned industry's ways of solving this problem inevitably leave a number of possible gaps in coverage, which are hard to accept by society. Some Argus-eyed European national authorities are ready to interfere if the expectations of the insured with respect to the matching of liability and insurance coverage are threatened not to be met.

To reconcile these opposing interests, the authors stress the importance of the technique of the "circumstances clause". This clause is allegedly able to fill most of the gaps in coverage between two succeeding insurance contracts, at least when some prior conditions are met. The most important of these conditions is that both succeeding insurers interpret the concept of 'circumstance' in the same way. Schoorens and Van Schoubroeck propose to link this definition to the well-known concept of 'duty to disclose'.

Gerhard Wagner's comments on the paper of Schoorens and Van Schoubroeck give some additional views on the issue. He recognises the power of the circumstances clause to create a solid bridge between two successive insurance policies $\mathrm{He}$ fears however that insurers will be reluctant to insert this clause because, in difficult areas with long tail liabilities, the pressure of the competitive market to cut prices will leave them with no other choice than to switch to loss occurrence or claims made triggers. This way the insurer can manage the risk more efficiently and, if things run out of hand, terminate the policy before it's too late. In addition, the knowledge that the insurer can cut off the tail, has efficiency enhancing effects of its own. The author states that this knowledge can act as an extra tool to counterbattle moral hazard and adverse selection. In the author's view the 
adoption of the circumstances clause would hamper the effective functioning of insurance markets.

In his paper on "Long tail Risks and Endogeneous Liabilities" Timothy Swanson investigates an interesting aspect connected with long tail risks, which requires state intervention. When a limited-liability firm operates in a context where it incurs benefits today and it can postpone the associated costs until some time in the future, the optimal strategy could be to wind up and liquidate the firm in the interim.

In this way costs arising out of long tail risks will be born by society, and the limited liability framework will in such a case turn out to be a free insurance for these firms.

When firms start to exploit this social insurance subsidy and to strategically liquidate, 'looting' occurs. This paper describes the conditions for looting and develops policy recommendations for the regulation by the state of this 'hit and run' strategy. The author sees a role for the private insurance market as a 'risk manager' for a limited period after the liquidation. The state will have to perform its role as policeman of anti-social behaviour, by organizing a monitoring system for the industries that are likely to develop this looting strategy. By charging the costs of these insurance mechanisms fully to the exact firms requiring them, the looting strategy would in the end disappear, rendering this system unnecessary.

\section{Competition and Information}

In the context of the second suggested conference theme (on competition in insurance and information of the consumer), Kruno Kukoc (of the "Insurance and Superannuation Commission" of Australia) gives an interesting description of insurance regulation and contemporary regulatory issues (dealing with disclosure of information) in Australia. Before doing so the paper briefly recalls the main market failures in insurance, the problems related to insurance regulation and the (what the author calls) three main pillars of information disclosure in insurance: disclosure of financial information, disclosure of information related to product, and disclosure of factors relevant to risk.

\section{Private Insurance and Social Insurance}

Addressing one aspect of the well-known debate on the proper balance between health care (and more generally social insurance) systems and (tort)liability-insurance systems, Michael Faure's paper examines the (relatively new) question to what extent private insurance principles can be applied to and are reconcilable with social insurance. Several questions are treated: what the main features of private insurance and of social insurance are; whether it is desirable to introduce compulsory insurance for health care; to what extent regulation of providers of care affects the price of the health care system; how the private insurance does compare with government provided schemes; and finally the question what the legal boundaries are to the "privatisation" of public health care systems (such as international conventions emanating from the International Labour Organisation, and the European Social Charter). The concluding remarks concerning the mutual influence which private and social insurance may exercise upon each and the possible combination of private and social formula's let appear a rather affirmative answer to the initial question. 


\section{Legal expenses insurance}

Two papers concern questions relating to the law and economics of legal expenses insurance and to its influence on the access to justice.

In Rickman's and Fenn's paper on Recent Developments in England and Wales, legal expense insurance is placed alongside other mechanisms such as traditional legal aid and the so-called conditional fee arrangements. Whereas under the English "Courts and Legal Services Act (1990)", the rule is that if a legally aided litigant loses his case, his opponent cannot recover costs, this expedient is not available under the other two systems. These systems are thus disadvantaged by the uncertainty which reigns under a "loser pays" cost rule. The paper is concerned with documenting the extent of litigation risks in the case of unaided litigants, with reviewing some proposals put forward by Lord Woolf's review of the civil justice system, and with examining the impact of these proposals on the future of legal expenses insurance.

Observing that economic models of legal disputes have not paid much attention to the impact of insurance on the conduct of cases, the second paper on legal expenses insurance, by Bowles and Rickman, make a start with filling up this gap. They tackle the question to what extent the interests of the insurer will influence the lawyer's behaviour, and their answer is that it will depend upon the structure of the contract between the insurer and the lawyer, whether the lawyer will rather collide with the client (against the insurer) or with the insurer (against the client). Their thesis, so the authors claim, appears to be backed up by recent UK experience. In an expanding legal expense insurance market, insurers will have to look for the right balance in their contracts with lawyers between the control of agency costs and the provision of legal services of appropriate quality. In the social insurance sector, recent proposals of the Lord Chancellor's department seem to have chosen in this respect for a radical solution to the "control of expenditure" problem.

\section{Development risk}

Göran Skogh's paper on "Development Risks, Strict Liability and the Insurability of Industrial Hazards" tries to extend the economic analysis of liability to new areas where 'uncertainty' prevails and/or insurance is not available.

The author first discusses the concepts of 'risk' and 'uncertainty' and distinguishes between actuarial (quantifiable) risks, development risks (not known) and unpredictable risks (known but non quantifiable).

Skogh then describes various forms of financial risk management, such as internal and external diversification, liability and first-party insurance, mutual risk-sharing, and public compensation schemes, and examines their ability to provide coverage for industrial accident costs. He concludes that the choice for one of these risk management forms will depend on the possible size of the accident (smaller or larger than the assets of the firm), the type of the risk (actuarial, predictable, development risk), and the type of the firm (closely held or widely held, i.e. without or with access to financial markets). The author concludes by pointing out some possible roads and directions for further research. 
The editors would like to thank both the Institute of Law and Economics of the University of Hamburg, which took care of the organisation of the conference and the insurance company Hanse Merkur, which hosted the conference in their nice office buildings facing the Alster Lake. All participants keep wonderful memories of an intellectually, interesting and most agreeable conference. The editors hope that the papers published in this volume will provide the reader with fresh insights concerning some of the sensitive problems facing the insurance industry today. 